\title{
Effects of adjuvants on herbicidal action. I. Effects of a mixture of adjuvants on diclofop-methyl retention and penetration in wheat and ryegrass
}

\author{
C Gauvrit, JL Dufour \\ INRA, laboratoire de malherbologie, BV 1540, 21034 Dijon Cedex, France
}

(Received 6 June 1990; accepted 18 September 1990)

\begin{abstract}
Summary - A mixture of adjuvants composed of a liquid nitrogenous fertilizer, oil, solvent and surfactant increases diclofop-methyl efficacy against ryegrass (Lolium multiflorum Lam) at application volumes varying from 75 to $500 \mathrm{loha}^{-1}$. The mixture only slightly affects spray retention on ryegrass (whatever the applied volume) and on wheat

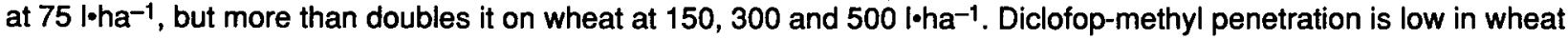
(less than $10 \%$ in 3 days) as well as through the wettable abaxial surface of ryegrass (less than $5 \%$ ). By contrast, penetration through the poorly wettable adaxial surface of ryegrass is $29 \%$ and $52 \%$ at 75 and 500 loha ${ }^{-1}$ respectively. The mixture increases herbicide penetration in both species: 2 to 3 times in ryegrass and 4 to 11 times in wheat, according to application volume. Oil plays a major part in this stimulation. Combined effects on retention and penetration lead to an increase in herbicide entry into the plants, which explains the higher efficacy. The increase is 3 to 4 times greater in wheat than in ryegrass, and this tends to diminish selectivity.
\end{abstract}

diclofop-methyl / adjuvant / retention / penetration / efficacy

Résumé - Effets des adjuvants sur l'action herbicide. I. Effet d'un mélange d'adjuvants sur la rétention et la pénétration du diclofop-méthyl chez le blé et le ray-grass. Un mélange d'adjuvants contenant de l'engrais azoté liquide, une huile, un solvant et un mouillant améliore l'efficacité du diclofop-méthyl sur ray-grass ( Lolium multiflorum Lam) pour des volumes d'application variant de 75 à 500 loha- ${ }^{-1}$ (fig 1). Le mélange d'adjuvants affecte peu la rétention de la pulvérisation par le ray-grass, quel que soit le volume d'application, et par le blé à 75 I.ha- $^{-1}$; par contre il la double pour le blé à 150, 300 et 500 loha-1 (fig 2). Le diclofop-méthyl pénètre mal chez le blé (moins de 10\% en $3 \mathrm{j}$, fig 4) ainsi que par la face abaxiale (mouillable) du ray-grass (moins de 5\%, fig 3A). Par contre, la pénétration est $29 \%$ (à 75 loha-1) et $52 \%$ (à 500 1.ha- ${ }^{-1}$ ) par la face adaxiale (peu mouillable) (fig 3B). Le mélange d'adjuvants stimule fortement la pénétration de l'herbicide dans les 2 plantes, d'un facteur 2 à 3 chez le ray-grass et 4 à 11 chez le blé, selon le volume appliqué (figs 3 et 4). L'huile joue le rôle essentiel dans cette augmentation (fig 5). II résulte de ces effets une augmentation de la quantité d'herbicide entrant dans les plantes, ce qui explique l'amélioration d'efficacité. Cet accroissement est 3-4 fois plus important chez le blé que chez le ray-grass, ce qui tend à diminuer la sélectivité de l'herbicide.

diclofop-méthyl / adjuvant / rétention / pénétration / efficacité

\section{INTRODUCTION}

During the last few years the use of adjuvants in herbicide applications has gained considerable popularity among French farmers. It is often associated with a lower treatment volume and herbicide dosage, as well as an earlier application time. The most commonly used adjuvant is a complex mixture (see Materials and Methods) comprising mineral oil, surfactant, solvent and liquid nitrogenous fertilizer. The benefits of this technique are currently under debate. Few question the increase in herbicide efficacy against weeds; however doubts have been raised about its innocuity on crops. For example, in field experiments, Orlando and Jouy (1990) found that the mixture of adjuvants brought about phytotoxicity symptoms in wheat (Triticum sativum $\mathrm{L}$ ) treated with diclofop-methyl. In contrast, Bouchet and Beaufreton (1988), while observing increased efficacy of diclofopmethyl and isoproturon against ryegrass (Lolium multiflorum $L a m$ ), wild-oat (Avena fatua $L$ ) and blackgrass (Alopecurus myosuroides Huds) found no injury to wheat. $A$ reason for this discrepancy could be that environmental conditions 
play a great part in the appearance of injury in crops. Field trials are underway to elucidate this point.

To our knowledge, no report on the action of such complex mixtures has yet been published but the action of individual components has been well documented. Oils increase droplet spreading on plants (Mc Whorter and Barrentine, 1988; Wanamarta et al, 1989; Schott et al, 1990) and herbicide penetration (Gillepsie et al, 1988; Grafstrom and Nalewaja, 1988; Mc Call, 1988; Wanamarta et al, 1989; Gauvrit and Dufour, 1990; Schott et al, 1990). Wetting agents increase spray retention (Harper and Appleby, 1984; O'Donovan et al, 1985; Anderson et al, 1987; De Ruiter and Uffing, 1988) and in some instances penetration as well (Sharma et al, 1978; Harper and Appleby, 1984; O'Donovan et al, 1985; De Ruiter and Uffing, 1988). Solvents help to impede active ingredient precipitation when it is close to its solubility limit (Galoux et al, 1986), thus maintaining it in the physical state most suitable for passage through the cuticle. Liquid nitrogenous fertilizers are hygroscopic (Norden, 1988) and prevent the deposit from drying completely, which is thought to promote penetration (Stevens et al, 1988).

We have sought to establish what effect the mixture of adjuvants has on two important efficacy parameters, namely retention and penetration, when diclofop-methyl is applied on ryegrass and wheat, a weed control situation commonly encountered in France.

\section{MATERIALS AND METHODS}

\section{Plant material}

Wheat (Triticum sativum L, cv Pernel) and ryegrass (Lolium multiflorum L, cv Adret) seeds were germinated at $25^{\circ} \mathrm{C}$ and sown in a clay loam soil: sand mixture (1:1). Ryegrass plants were then placed in a growth cabinet at $14 / 9^{\circ} \mathrm{C}$ (day/night), $14 \mathrm{~h}$ photoperiod and $65 / 95 \%$ relative humidity. Wheat plants were placed in the same conditions except for day temperature: $17^{\circ} \mathrm{C}$. All experiments were performed when the third leaf was 1 to $3 \mathrm{~cm}$ long.

\section{Diclofop-methyl efficacy on ryegrass}

Diclofop-methyl was applied as an Illoxan CE emulsion. Illoxan CE is an emulsifiable solution which contains $36 \%$ diclofop-methyl, $49 \%$ aromatic solvents and
$15 \%$ anionic emulsifiers. The emulsion was applied by means of an indoor sprayer consisting of a movable boom with two "Albuz" $110^{\circ}$ nozzles positioned $50 \mathrm{~cm}$ apart: grey nozzles operated at 4.0 bars for 300 and $5001 \cdot h^{-1}$, blue nozzles operated at 3.0 bars for 150 l.ha ${ }^{-1}$, red nozzles operated at 2.0 bars for 75 l.ha ${ }^{-1}$. Plants were placed $48 \mathrm{~cm}$ under the nozzles and were sprayed with $150 \mathrm{~g}^{\cdot h \mathrm{a}^{-1}}$ diclofop-methyl. From the mixture compositions commonly used by farmers, we chose the following one. Solvent: $0.51 \cdot \mathrm{ha}^{-1}$ isophorone (Prolabo); surfactant (non-ionic): 0.1 loha-1 Citowett $(100 \%$ alkyl-aryl phenol polyglycol ether (5 ethylene oxide), BASF Co); oil: $0.51 \cdot$ ha $^{-1}$ Végélux ( 840 $\mathrm{g}^{\circ-1}$ emulsifiable mineral oil, CCL Co); 5 l.ha-1 liquid nitrogenous fertilizer (39\% ammonium nitrate, $39 \%$ urea). The oil emulsifier was occasionally tested at a 0.12 loha-1 dose.

At the stage defined above, plants were sprayed at the chosen volume, with or without the mixture of adjuvants. Nine replications with 8 plants each were carried out for each treatment and after $14 \mathrm{~d}$ under the growth conditions the shoots were cut off at ground level and placed at $80^{\circ} \mathrm{C}$ for $24 \mathrm{~h}$ for dry weight determination.

\section{Retention measurements}

Plants were sprayed under the same conditions as for the efficacy experiments except that diclofop-methyl

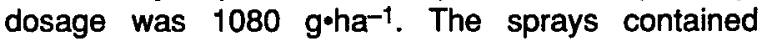
$0.01 \%$ fluorescein as in Richardson's experiments (1984). After the spray had dried on the foliage, the plants were cut off at ground level and shaken for $30 \mathrm{~s}$ in $50 \mathrm{ml} 5 \mathrm{mM} \mathrm{NaOH}$. Readings were made in a Jobin and Yvon 3-D spectrofluorimeter at $490 / 510 \mathrm{~nm}$. Plants were then placed at $80^{\circ} \mathrm{C}$ for $24 \mathrm{~h}$ and the dry matter weighed. For ryegrass, experiments comprised 6 repetitions with 25 plants each and for wheat, 3 repetitions with 10 plants each.

\section{Diclofop-methyl penetration}

Ring ${ }^{14} \mathrm{C}$ labelled diclofop-methyl (257 $\mathrm{MBq} \cdot \mathrm{mmol}^{-1}$, $98.5 \%$ radiochemical purity) was dissolved in ethanol. An aliquot containing the desired radioactivity was deposited at the bottom of a conical tube and the ethanol evaporated to dryness. An aqueous emulsion of Illoxan CE was then added at a concentration corresponding to a $1080 \mathrm{~g}^{\circ} \mathrm{ha}^{-1}$ diclofop-methyl, at either a 75 or $500 \mathrm{l}^{-\mathrm{ha}^{-1}}$ treatment. Gentle shaking for $2 \mathrm{~h}$ interspersed with two $10 \mathrm{~s}$ sonication spells redissolved radiolabelled diclofop-methyl. Radioactivity of the preparation was $16.7 \mathrm{~Bq} \cdot \mu \mathrm{I}^{-1}$ and cold herbicide was $99.0 \%\left(500 \mathrm{l}^{-h a^{-1}}\right)$ or $99.8 \%\left(75 \mathrm{l}^{-} \mathrm{ha}^{-1}\right)$ of total herbicide. Adjuvant concentrations in the applied emulsion corresponded to that defined above and were calculated on a ha basis. It follows that adjuvant concentrations were 6.7 times higher in conditions corresponding to $75 \mathrm{loha}^{-1}$ treatments than in $500 \mathrm{I}^{-h^{-1}}$ treatments. 
Four $0.5-\mu$ ldroplets of the above emulsion were deposited on the upper third of the 2nd leaf and the plants placed in a growth cabinet at $17 / 9^{\circ} \mathrm{C}$ (day/night), $14 \mathrm{~h}$ photoperiod and $65 / 95 \%$ relative humidity. Penetration was studied on the adaxial surface of wheat and on both abaxial and adaxial surfaces of ryegrass. Absorption was determined 1 and $3 \mathrm{~d}$ after treatment. Each measurement was made on 5 plants from the same pot and the experiment was conducted with 3 replicates. Absorption was evaluated by washing the treated area of each leaf with $1 \mathrm{ml}$ acetone and then 1 $\mathrm{ml}$ of chloroform. Washes were combined and evaporated to dryness. Ethanol was added to dissolve diclofop-methyl which was counted in Dynagel (JT Baker Chemicals, The Netherlands) by scintillation counting. Leaves were dried $\left(24 \mathrm{~h}, 80^{\circ} \mathrm{C}\right)$ and combusted in an oxidizer for radioactivity assessment. Recovery figures varied from 81 to $104 \%$.

\section{Statistics}

The experiments were full factorial (efficacy and retention studies: 2 factors; penetration studies: 3 factors). Data were submitted to analysis of variance and means were compared using the Newman-Keuls test at the 5\% level (Cochran and Cox, 1968). Data marked with the same letters in the figures and tables do not differ significantly.

\section{RESULTS}

\section{Dlclofop-methyl efficacy on ryegrass}

Efficacy was higher at 150 to $5001 \cdot \mathrm{ha}^{-1}$ than at $75 \mathrm{l}^{\circ} \mathrm{ha}^{-1}$ (fig 1). The mixture of adjuvants improved diclofop-methyl efficacy by 11 to $21 \%$. There was no volume $x$ adjuvant interaction.

\section{Retention}

The retention of Illoxan CE sprays was higher on ryegrass than on wheat: 2.2 times at $751 \cdot$ ha $^{-1}$ and 4.9 times at $500 \mathrm{loha}^{-1}$ (fig 2). Retention was roughly proportional to the applied volume on ryegrass but such a relationship was not observed on wheat. Another difference between the two plants was that on ryegrass, retention was not affected by the mixture of adjuvants whereas in wheat it was increased at 150, 300 and $500 \mathrm{l}^{-h^{-1}} \mathrm{a}^{-1}$ Statistical analysis revealed a volume $x$ adjuvant interaction, the adjuvant effect being all the more important the higher the volume.

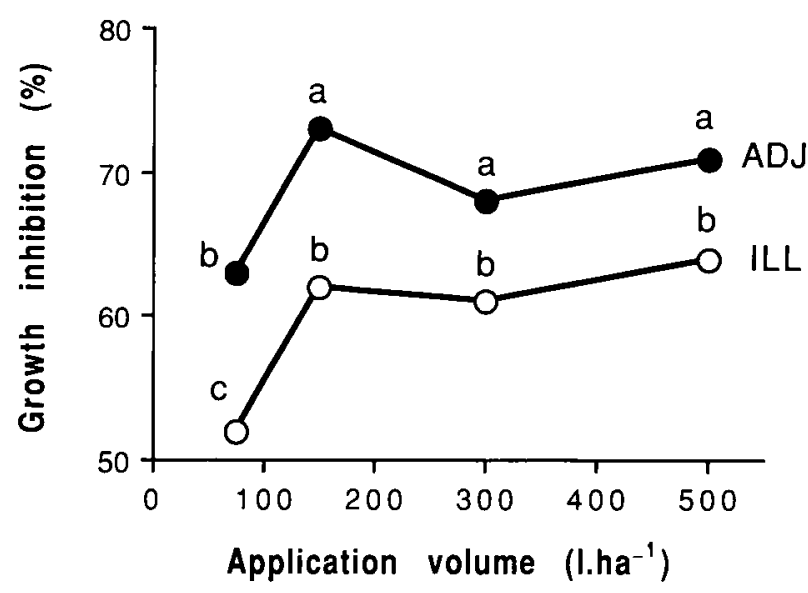

Fig 1. Effect of diclofop-methyl on ryegrass growth as influenced by the mixture of adjuvants and the application volume. Growth was defined as the dry matter increase between treatment and harvest. Growth inhibition is expressed as \% control growth ( $1.563 \pm 0.141 \mathrm{~g}$ dry matter). ILL: treatment with an Illoxan CE emulsion; ADJ: treatment with an Illoxan CE emulsion combined with the mixture of adjuvants.

The increase in retention on wheat could not be attributed to a single adjuvant (table I).

\section{Penetration}

Diclofop-methyl penetration through the abaxial surface of ryegrass was low: after 3 days it amounted to less than $3 \%$ of the applied radiolabelled diclofop-methyl at $751 \cdot \mathrm{ha}^{-1}$ and $5.3 \%$ at 500 leha $^{-1}$ (fig 3A). The mixture of adjuvants increased penetration to $11.7 \%$ and $8.5 \%$ at 75 and $5001 \cdot \mathrm{ha}^{-1}$ respectively. There was no volume effect but a volume $x$ adjuvant, interaction; adjuvant effect being lower at high volume.

Table I. Retention of a spray of lloxan CE emulsion on wheat as influenced by adjuvants.

\begin{tabular}{lc}
\hline \multicolumn{1}{c}{ Adjuvant } & $\begin{array}{c}\text { Retention } \\
\left(\mu / g^{1} d r y \text { matter }\right)\end{array}$ \\
\hline None & $59.6^{\mathrm{a}}$ \\
Liquid nitrogenous fertilizer & $68.9^{\mathrm{a}}$ \\
Emulsifer & $42.8^{\mathrm{a}}$ \\
Oil & $49.5^{\mathrm{a}}$ \\
Solvent & $60.8^{\mathrm{a}}$ \\
Wetting agent & $47.8^{\mathrm{a}}$ \\
Mixture of adjuvants & $90.0^{\mathrm{b}}$ \\
\hline
\end{tabular}

* Values followed by the same letter do not differ significantly. 


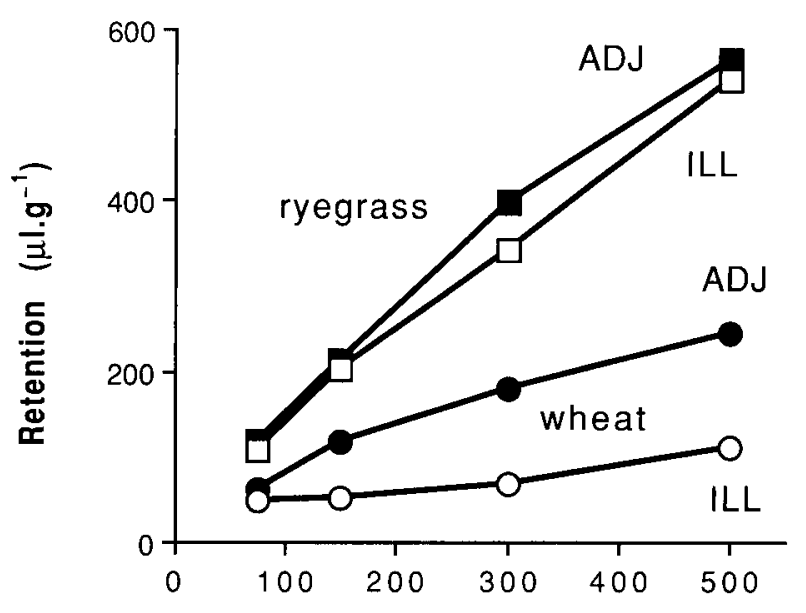

Application volume $($ l.ha-1)

Fig 2. Effect of the mixture of adjuvants on spray retention by ryegrass and wheat. ILL, ADJ: (see fig 1).

After 3 days, diclofop-methyl penetration through the adaxial surface of ryegrass amounted to $28.7 \%$ and $51.8 \%$ at 75 and $500 \mathrm{l}^{\circ} \mathrm{ha}^{-1}$ respectively (fig 3B). The mixture of adjuvants increased it to $80.0 \%\left(751 \cdot \mathrm{ha}^{-1}\right)$ and $92.2 \%(500$ 1-ha-1). Penetration was significantly higher at $500 \mathrm{l}^{\circ} \mathrm{ha}^{-1}$ but there was no volume $\mathrm{x}$ adjuvant interaction.

When diclofop-methyl was administered in the commercial preparation, its penetration into wheat was low: $5.7 \%$ at $7510 \mathrm{ha}^{-1}$ and $10.5 \%$ at $500 \mathrm{l}^{\circ} \mathrm{ha}^{-1}$ after 3 days (fig 4). The mixture of adjuvants dramatically increased penetration to $65.0 \%$ and $41.8 \%$ respectively. The effect was stronger at $75 \mathrm{loha}^{-1}$.

When added individually to Illoxan CE emulsion, adjuvants exhibited different effects on diclofop-methyl penetration (fig 5). The emulsifier, Citowett and isophoron had no significant effect. Liquid nitrogenous fertilizer and Végélux oil improved penetration, the oil effect not being significantly different from that of the complete mixture.

\section{DISCUSSION}

\section{Diclofop-methyl efficacy on ryegrass}

Diclofop-methyl efficacy is lower at 75 1.ha-1 than at 150 to $500 \mathrm{loha}^{-1}$ (fig 1). At high volumes, concentration of the active ingredient is low but foliage coverage is good; however, at lower volumes the herbicide concentration is high, at the
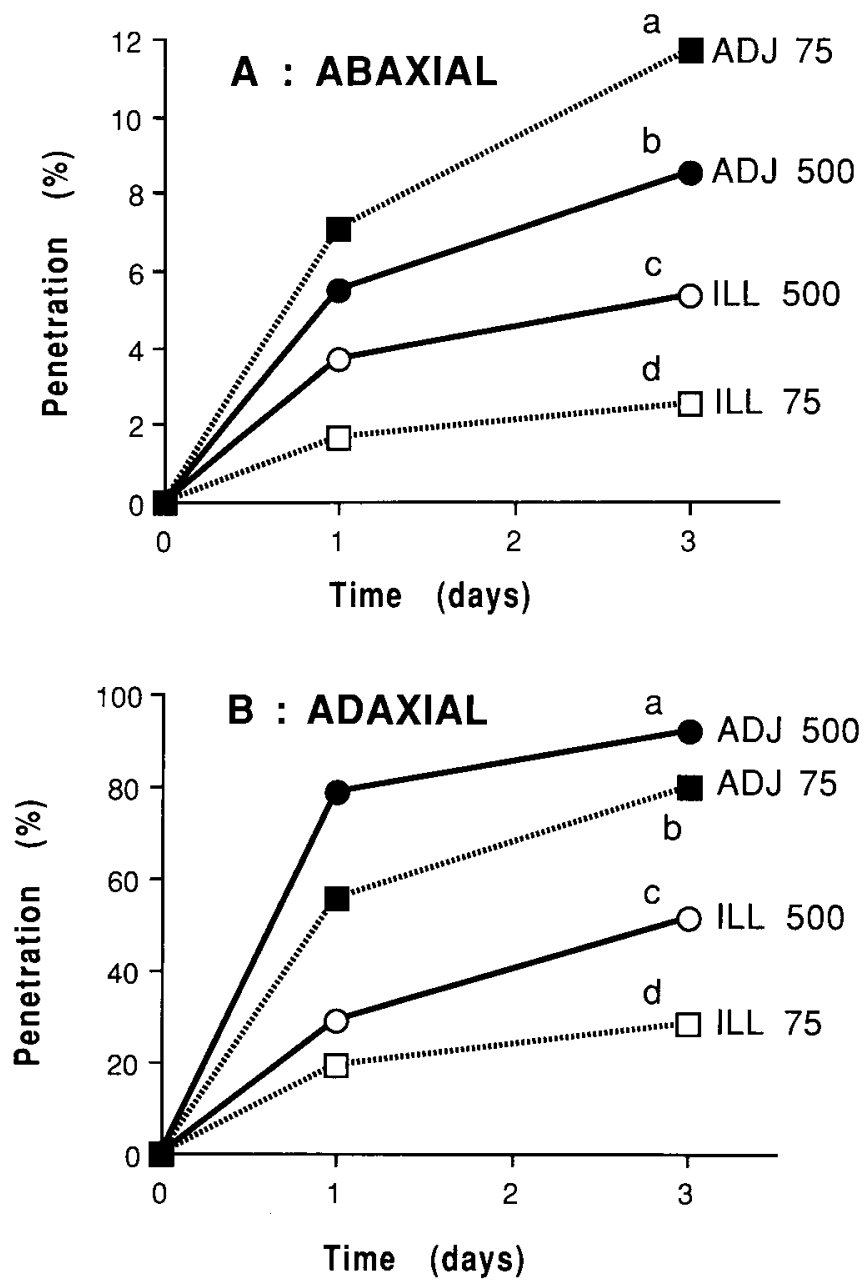

Fig 3. Diclofop-methyl penetration through the abaxial (A) and adaxial $(B)$ surfaces of ryegrass as influenced by the mixture of adjuvants and the application volume. ILL, ADJ: (see fig 1), 75, 500 : I.ha-1. Note scale difference on the penetration axis.

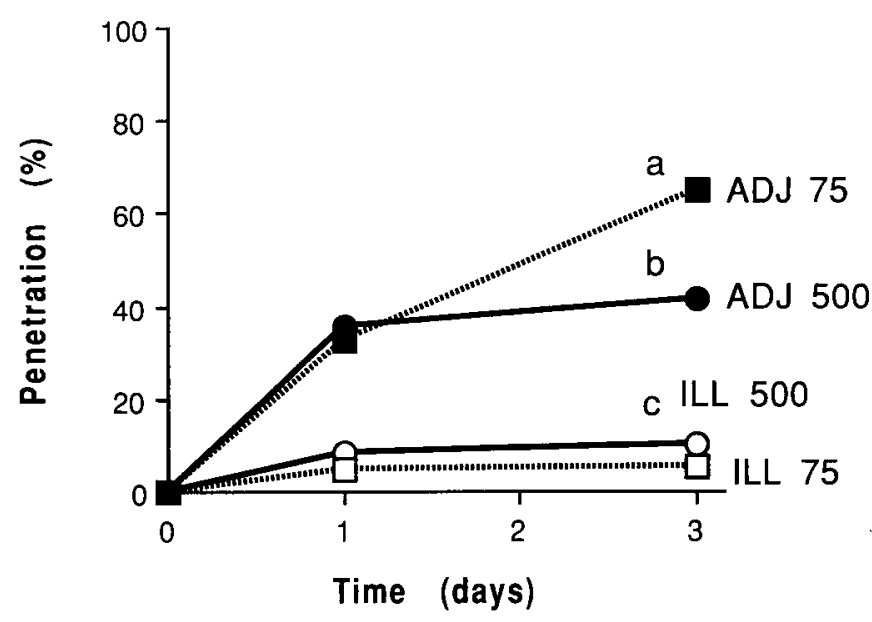

Fig 4. Diclofop-methyl penetration through the adaxial surface of wheat. ILL, ADJ, 75, 500: (see fig 3).

expense of foliage coverage. A few herbicides are more active at high concentrations, for instance glyphosate (Ambach and Ashford, 1982; Merritt, 1982; Kudsk, 1988) and phenmedipham 


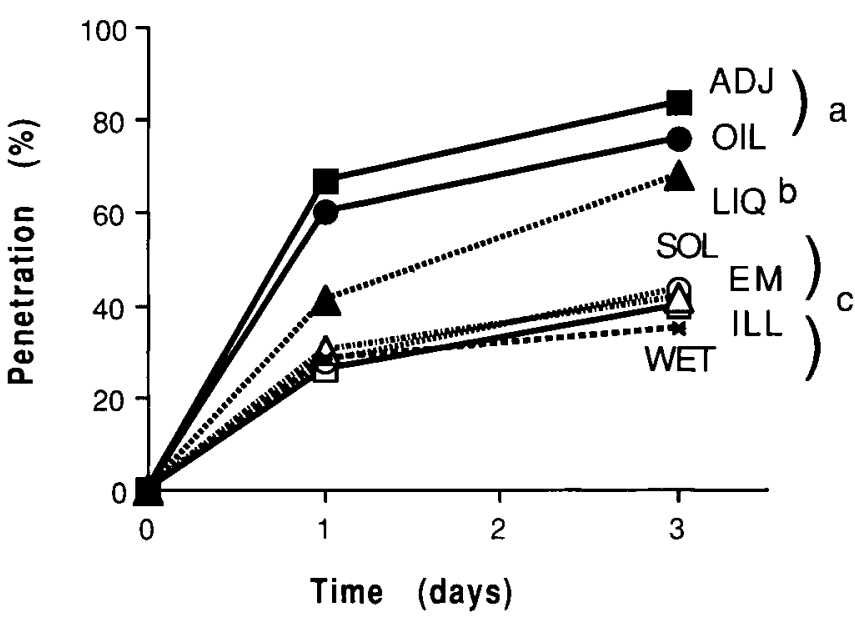

Fig 5. Diclofop-methyl penetration through the adaxial surface of ryegrass as influenced by adjuvants. $A D J, \boldsymbol{E}:$ mixture of adjuvants; EM, $\Delta$ : emulsifer; ILL, D: Illoxan; LIQ, $\triangle$ : liquid nitrogenous fertilizer; OIL, ๑: oil; SOL, O: solvent; WET, $\mathbf{X}$ : wetting agent

(Bishof, 1988). In contrast, contact herbicides are generally thought to require high application volumes to exert maximal action (Taylor, 1981), but this opinion is not shared by Skuterud et al (1988). Our results show that diclofop-methyl falls into the second category, although its action cannot be qualified as contact. It must be stressed that since we used different nozzles to deliver the various application volumes, differences in droplet spectra might have played a part in the observed differences in efficacy.

The mixture of adjuvants improved diclofopmethyl efficacy by 11 to $21 \%$. This increase was somewhat less extensive than that observed by Bouchet and Beaufreton (1988). However, these authors had measured diclofop-methyl efficacy 30 and 60 days after treatment, whereas we made our observations 14 days after treatment. As diclofop-methyl is a slow acting herbicide, this could explain why our results are qualitatively but not quantitatively in agreement.

\section{Retention}

As shown by Schott et al (1990) the high wettability of Lolium multiflorum is due to the exposure of the abaxial surfaces towards the spray at the 3leaf stage. Diclofop-methyl spray retention on wheat is noticeably lower, which is in agreement with the selectivity of this herbicide.

It is also worth noting that in ryegrass, retention is roughly proportional to the applied volume whereas such a relationship is not found in wheat. From the shape of the two curves (fig 2) it follows that lowering the applied volume at constant dosage per ha does not alter the amount of active ingredient collected by ryegrass but increases it in wheat. For example, whilst retention by wheat is divided by 2.2 when the volume is lowered from 500 to $75 \mathrm{I}^{-\mathrm{ha}^{-1}}$, collection of the active ingredient is increased by 3.0 .

The two preceding remarks show that when diclofop-methyl is applied to wheat to control ryegrass, volume reduction tends to lower selectivity. However, the predominant selectivity factor in this case is diclofop-methyl degradation by wheat (Shimabukuro et al, 1979; Boldt and Putnam, 1981).

In ryegrass we observed no increase in retention upon addition of the mixture of adjuvants to the Illoxan CE emulsion. This is in line with observations by Blackman et al (1958) and De Ruiter and Uffing (1988) who found that on wettable plants the increase in retention by surfactants was either nil or limited. However, in wheat the mixture of adjuvants increased retention (fig 2). The effect was not noticeable at 75 l-ha- ${ }^{-1}$, possibly because at such a volume the concentration of the adjuvants already present in the commercial preparation is high. Surface tension of Illoxan CE emulsions is low: 30 to $31 \mathrm{mN} \cdot \mathrm{m}^{-1}$ (Schott et al, 1990), indicating the presence of tensio-active substances. Their concentration may be so high at $751 \cdot \mathrm{ha}^{-1}$ that further addition of surfactants through the mixture of adjuvants does not improve their action on retention. This explanation is in line with the shape of the retention curve for wheat, which levels off as the applied volume decreases.

Since the increase in retention cannot be attributed to a single adjuvant (table I), we can hypothesize that it is the result of a synergy between two or more components of the mixture, but so far we have not carried out any experiments to verify this idea.

\section{Penetration}

The two ryegrass (Lolium perenne $L$ ) leaf surfaces have different properties with regard to wettability (Field and Bishop, 1988). Contact angles of formulated glyphosate droplets are $36^{\circ}$ and $118^{\circ}$ for the abaxial and the adaxial surface respectively. The latter is covered with dense deposits of crystalline wax whereas the abaxial surface presents amorphous epicuticular waxes. We found the same wettability difference be- 
tween the two leaf surfaces of Lolium multiflorum (Schott et al, 1990). In addition, we have shown that diclofop-methyl penetration is one order of magnitude higher on the adaxial surface. This is reminiscent of Holloway and Silcox's observations (1985) that non-ionic surfactant penetration is faster through waxy leaves such as rape (Brassica napus L) and pea (Pisum sativum L) which possess microcrystalline wax deposits on the surface.

In the absence of adjuvants, diclofop-methyl penetration was always higher at $500 \mathrm{l}^{\mathrm{h} \mathrm{h}^{-1}}$ than at $75 \mathrm{l}^{\circ} \mathrm{h}^{-1}$, which might explain why efficacy on ryegrass was lower at $75 \mathrm{l} \cdot \mathrm{ha}^{-1}$ than

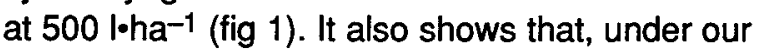
conditions, increasing the concentrations of the active ingredient and adjuvants does not promote penetration.

The mixture of adjuvants drastically increases diclofop-methyl penetration in ryegrass (fig 3 ) which very probably explains the improvement in herbicidal efficiency upon their addition. However, the beneficial effect of high volumes which was observed in biological tests (fig 1) was found only on the adaxial surface with regard to penetration.

All adjuvants present in the mixture do not participate equally in the increase in penetration. The solvent (isophoron), the emulsifier and the surfactant (Citowett) have no detectable effect.

Isophorone's lack of action is understandable since diclofop-methyl is in a dissolved state in the emulsion. Both the emulsifier and Citowett could be expected to increase diclofop-methyl penetration since surfactants can promote herbicide entry into plants (Sharma et al, 1978; Harper and Appleby, 1984; O'Donovan et al, 1985). However, since llloxan CE is an emulsion, there is an emulsifier present in the commercial preparation. This might be the reason why further addition of this type of compound does not affect diclofop-methyl penetration.

Liquid nitrogenous fertilizer increases diclofopmethyl penetration, as it increases the efficacy of some herbicides (Horn et al, 1986; Chow, 1988), but not all (Sander et al, 1987). Liquid nitrogenous fertilizer is hygroscopic (Norden, 1988) and maintains an aqueous environment inside the deposit. It favours penetration (Stevens et al, 1988) since the activity and the diffusion of the active ingredient are maintained (Price, 1982). We observed that in the presence of the mixture of adjuvants the deposits never took on the appearance of a white precipitate as was the case with Illoxan CE emulsion alone. However, Babiker and Duncan (1975) have shown that humectants such as glycerol and sorbitol reduce aminotriazole penetration into bracken (Pteridium aquilinum $\mathrm{L}$ ).

The action of oils is poorly understood, even though numerous reports show that they promote herbicide entry into plants (Gillepsie et al, 1988; Grafstrom and Nalewaja, 1988; McCall, 1988; Wanamarta et al, 1989; Gauvrit and Dufour, 1990; Schott et al, 1990). The fact that the addition of oil brings about the same stimulation of penetration as the complete mixture of adjuvants, together with the lack of effect of the mixture on retention by ryegrass, confirms outdoor results that oil also plays the predominant role in the increase in efficacy (Bouchet and Beaufreton, 1988). It also indicates that the mixture might be too complicated for its purpose.

Combining the effects on retention and penetration it follows that at $751 \cdot \mathrm{ha}^{-1}$ the mixture of adjuvants increases 3 to 4 times the amount of diclofop-methyl that enters ryegrass, whereas the corresponding figure for wheat is 11.5. At $500 \mathrm{loha}^{-1}$ these figures are 2 and 8 respectively. Hence, the mixture of adjuvants increases herbicide entry into plants more in wheat than in ryegrass, which is adverse to selectivity. In this respect, field trials have shown that, even at reduced diclofop-methyl dosage, oil addition can cause injury to wheat (Orlando and Jouy, 1990). However, Bouchet and Beaufreton (1988) in outdoor experiments with the same mixture of adjuvants showed increased activity against ryegrass and a lack of phytotoxicity against wheat. Hence, the increase of herbicide entry in wheat only produces injury under certain conditions which remain to be defined.

\section{ACKNOWLEDGMENTS}

This work is part of the project "Adjuvants for optimization of pesticide utilization" initiated by ACTA, France. We wish to thank $\mathrm{CCL}$ Co, France, for the supply of Végélux and its emulsifier, Hoechst Co, Germany, for the generous gift of radiolabelled diclofop-methyl and ND Polge for his aid during the preparation of the manuscript.

\section{REFERENCES}

Ambach RM, Ashford R (1982) Effects of variations in drop makeup on the phytotoxicity of glyphosate. Weed Sci 30, 221-224 
Anderson NH, Hall DJ, Seaman D (1987) Spray retention: effects of surfactants and plant species. Aspects Appl Biol 14, 233-243

Babiker AGT, Duncan HJ (1975) Penetration of bracken fronds by amitrole as influenced by pre-spraying conditions, surfactants and other additives. Weed Res 15, 123-127

Bishof $F$ (1988) Unkrautbekämpfung in Zuckerrüben mit reduzierten Herbizidmengen. $Z$ Pflanzenkr Pflanzenschutz. Sonderheft XI, 431-437

Blackman GE, Bruce RS, Holly K (1958) Studies in the principles of toxicity. V. Interrelationships between specific differences in spray retention and selective phytotoxicity. J Exp Bot 9, 175-205

Boldt PF, Putnam AR (1981) Selectivity mechanisms for foliar applications of diclofop-methyl. II. Metabolism. Weed Sci 29, 237-241

Bouchet C, Beaufreton C (1988) Incidence de l'utilisation d'adjuvants sur l'efficacité de deux herbicides. EWRS Symp Wageningen. Factors affecting herbicidal activity and selectivity, 375-380

Chow PN (1988) Wild-oat herbicide studies: barban herbicidal activity for wild-oat (Avena fatua $L$ ) control as influenced by adjuvants. Crop Prot 7, 3-8

Cochran WG, Cox GM (1968) Experimental Designs, 2nd ed, John Wiley \& Sons, New York, pp 76-78

De Ruiter H, Uffing AJM (1988) The influence of surfactants and plant species on the retention of spray solutions. EWRS Symp Wageningen, Factors affecting herbicidal activity and selectivity, 163-168

Field RJ, Bishop NG (1988) Promotion of stomatal infiltration of glyphosate by an organosilicone surfactant reduces the critical rainfall period. Pestic Sci 24, 55-62

Galoux M, De Ryckel B, Bernes A, Van Damme JC (1986) Le phénomène de cristallisation du phenmédiphame en émulsion. Parasitica 42, 71-91

Gauvrit C, Dufour JL (1990) Effect d'un mélange d'adjuvants sur les paramètres d'efficacité du diclofop-méthyl. 14th Conf COLUMA, Versailles, 23-24 january, 137-145

Gillepsie GR, Skrzypczak GA, Nalewaja JD (1988) Absorption and translocation of CGA-82725 with additives. Weed Sci 36, 282-285

Grafstrom LD Jr, Nalewaja JD (1988) Uptake and translocation of fluazifop in green foxtail (Setaria viridis). Weed Sci 36, 153-158

Harper DR, Appleby AP (1984) Selectivity factors relative to asulam for Senecio jacobea L control in Medicago sativa L. I. Retention, uptake and translocation. Weed Res 24, 85-92

Holloway PJ, Silcox D (1985) Behaviour of three nonionic surfactants following foliar application. Proc British Corp Prot Conf Weeds 3C-5, 297-302

Horn R, Linke E, Grunert C, Motzka F, Zahn K, Greifenberg G (1986) Höhere Effektivität von Pflanzenschutzmaßnahmen durch die Kombination mit Ammonnitrat-Harnstoff-Lösung (AHL). Nachrichtenbl Pflanzenschutz DDR 40, 151-154
Kudsk $P$ (1988) The influence of volume rates on the activity of glyphosate assessed by a parallel-line assay technique. Pestic Sci 24, 21-29

McCall PJ (1988) Effect of chemical structure, temperature, crop oil concentrate, and bentazon on the behaviour of haloxyfop in yellow foxtail (Setaria glauca), a quantitative modeling approach. Weed Sci 36, 424-435

McWhorter CG, Barrentine WL (1988) Spread of paraffinic oil on leaf surfaces of johnsongrass (Sorghum halepense). Weed Sci 36, 111-117

Merritt CR (1982) The influence of form of deposit on the phytotoxicity of MCPA, paraquat and glyphosate applied as individual drops. Ann Appl Biol 101, 527-532

Norden J (1988) Basic physics of spray technique for the avoidance of evaporation and drift. Symp Intern Techn Application Produits Phytosan ANPP, Paris, 18-19 january, 11-18

O'Donovan JT, O'Sullivan PA, Caldwell CD (1985) Basis for changes in glyphosate phytotoxicity to barley by the non-ionic surfactants Tween 20 and Renex 36. Weed Res 25, 81-86

Orlando D, Jouy $L$ (1990) Optimisation de la rentabilité du désherbage du blé avec l'apport d'adjuvants. 14th Conf COLUMA, Versailles, 23-24 january, 155-161

Price CE (1982) A review of the factors influencing the penetration of pesticides through plant leaves. In: The Plant Cuticle (Cutler DF, Alvin KL, Price CE, eds) Academic Press, London, pp 237-252

Richardson RG (1984) Fluorescent tracer technique for measuring total herbicide deposits on plants. Aust Weeds 3, 123-124

Sander KW, Burnside OC, Bucy JI (1987) Herbicide compatibility and phytotoxicity when mixed with liquid fertilizers. Agron J 79, 48-52

Schott JJ, Dufour JL, Gauvrit C (1990) Effets d'huiles sur les paramètres d'efficacité du diclofop-méthyl appliqué sur raygrass. 14th Conf COLUMA, Versailles, 23-24 january, 147-154

Sharma MP, Van den Born WH, McBeath DK (1978) Spray retention, foliar penetration, translocation and selectivity of asulam in wild oats and flax. Weed Res 18, 169-173

Shimabukuro RH, Walsh WC, Hoerauf RA (1979) Metabolism and selectivity of diclofop-methyl in wild oat and wheat. J Agric Food Chem 27, 615-623

Skuterud R, Nordby A, Tyldum A (1988) Effects of application methods, spray volumes, pressures and herbicide rates on weed control in spring cereals. Crop Prot 7, 303-308

Stevens PJG, Baker EA, Anderson NH (1988) Factors affecting the foliar absorption and redistribution of pesticides. Pestic Sci 24, 31-53

Taylor WA (1981) Controlled drop application of herbicides. Outlook Agric 10, 333-336

Wanamarta G, Penner D, Kells JJ (1989) Identification of efficacious adjuvants for sethoxydim and bentazon. Weed Technol 3, 60-66 